\title{
Wood Residue Processing and Utilization in Southeastern Michigan, U.S.
}

\author{
Pascal Nzokou, Jessica Simons, and Anthony Weatherspoon
}

\begin{abstract}
This paper is an analysis of southeastern Michigan, U.S.'s wood residue processing and disposal facilities. The analysis was conducted in order to characterize wood supply patterns, evaluate recovery efficiency, and identify potential alternatives for wood residues. Wood collection and processing facilities were identified and surveyed throughout a 14-county area. This study documented at least 180 wood residue yards operating in the region, which employed an average of six employees per yard (for a total of 1,082 employees in the industry). The total volume of wood entering the yards was quantified at 6,659.6 thousand cubic meters (5.3 million metric tons), mainly from land-clearing and tree removal. The wood residue supply was used to produce a total of 2,035.8 thousand cubic meter (1.6 million tons) tons of new products (e.g., wood chips, mulches, firewood), which were mainly sold locally. The overall conversion rate was estimated at $30 \%$ for the entire industry, clearly indicating room for improvement. The industry is estimated to contribute approximately USD \$40 million to Michigan's economy. Improvement of conversion rates and value-added product development would require fundamental changes in equipment, training, and processes used by tree service and land clearing companies. Keywords. Disposal Yards; Urban Tree; Wood Residue; Wood Residue Recovery.
\end{abstract}

Wood residues include a large spectrum of wood products from primary and secondary processing such as bark, slabs, sawdust, chips, planer shavings, sander dust, end trims, used pallets, and construction residues. Wood residues also include logs, branches, and brush from urban tree removals, construction-related land clearing, farming, and industrial projects. Several studies and reports have indicated that large amounts of wood residues are generated annually in the United States. For example, in 2001, an estimated 234 million metric tons of residue was generated from traditional timber extraction, forest conversion to nonforest uses, primary processing, and demolition of buildings and structures in the United States (McKeever 1998). A regional outlook indicates that the Midwest has 21.2 million tons of recoverable wood residues, including 2.2 million tons of municipal solid waste, 1.5 million tons from construction sources, 2.6 million tons from demolition, 5.6 million tons of logging residues, and 2.8 million tons of other types of woody residuals (McKeever 2003). Studies in other regions also report significant wood residue generation, showing that this is a nationally relevant issue (Hubing 1993; De Hoop et al. 1994; Short and Hooper 1996; Murphy et al. 2007). A more recent study reports that 7.5 million cubic yards of urban wood residues are generated annually in the southeastern Michigan region alone, with $58 \%$ of the material being discarded (Sherrill and MacFarlane 2007).

Wood residues are traditionally mulched and used for bedding, compost, or as fuel for energy. However, it is estimated that wood residues accounted for about $17 \%$ of the total residues received at municipal landfills in the United States (Forest Products Laboratory 2002). Sherrill and MacFar- lane (2007) estimated that two million cubic yards of wood residue enters southeastern Michigan landfills each year.

Wood residue recovery programs in Michigan and nationally are generally targeted towards low-end markets such as chips and mulches, which pay the equivalent of USD $\$ 0.25$ for a recovered wood pallet, while products in the high-end markets, such as finished solid wood products could pay 20 to 32 times more for an equivalent amount of wood (Forest Products Laboratory 2002).

Studies have shown that there are several value-added options for conversion of residue wood. For example, wood residues can be converted into wood fuel pellets for use in residential stoves or included as filler in the manufacturing of wood composites (Alderman et al. 1999). In addition, numerous researchers, local governments, and private businesses have been successful in developing creative and profitable uses for residue wood (Bratkovich 2001; Haviarova et al. 2001; Forest Products Laboratory 2002; Grushecky et al. 2006).

The amount of wood residue generated in Michigan has recently changed due to the emerald ash borer (EAB) infestation, which killed more than 25 million ash trees across southern Michigan (Nzokou et al. 2006; McCullough and Siegert 2007). Previous studies have discussed the potential for using residue wood generated from the EAB infestation in the fabrication of valueadded products such as lumber for furniture, paneling, flooring, interior joinery, cabinetry, and pallets (Nzokou et al. 2006).

An important and necessary step in developing profitable and viable markets for residue wood is to quantify the amounts that are available by source and type of material, analyze current production patterns, and identify the potential for alterna- 
tive value-added options. Clearly understanding these factors is critical to maximizing the economic value of these resources.

The goal of this study was to assess the resource flow patterns for residue and green wood entering recycling yards and landfills in southeastern Michigan and to evaluate the potential for a better use of these resources.

\section{MATERIALS AND METHODS}

\section{Survey Methods}

This study focused on 14 counties in southeastern Michigan (Figure 1); these counties were also included in the wood residue generation survey study conducted by Sherrill and MacFarlane (2007).

A list of disposal yards and wood residue processing facilities (in the study area) was compiled by using the Michigan Department of Natural Resources database, local telephone directory listings, and lists provided by the Southeast Michigan Resource Conservation and Development Council. Telephone calls were made to each company listed to ensure that only those accepting wood residue were included. The corrected list for each county was forwarded County Directors of the Michigan State University Extension for validation, correction, and establishment of the final target population. A total 180 facilities were retained in the study.

A questionnaire was developed to collect data on quantity and types of resources entering the yards, and amounts and value of products generated. The questionnaire was evaluated and pretested by wood use professionals to ensure clarity and suitability. Mailings, reminders, and follow-up calls were conducted from October 2007 to May 2008. In addition to categorical questions to obtain basic information about each company, questions were asked to identify the origin of woody material entering the yards, to characterize processing facilities, identify species processed and product types, and obtain total volumes produced in each facility. Additional questions focused on current markets, marketing strategies, and bottlenecks that prevent higher productivity.

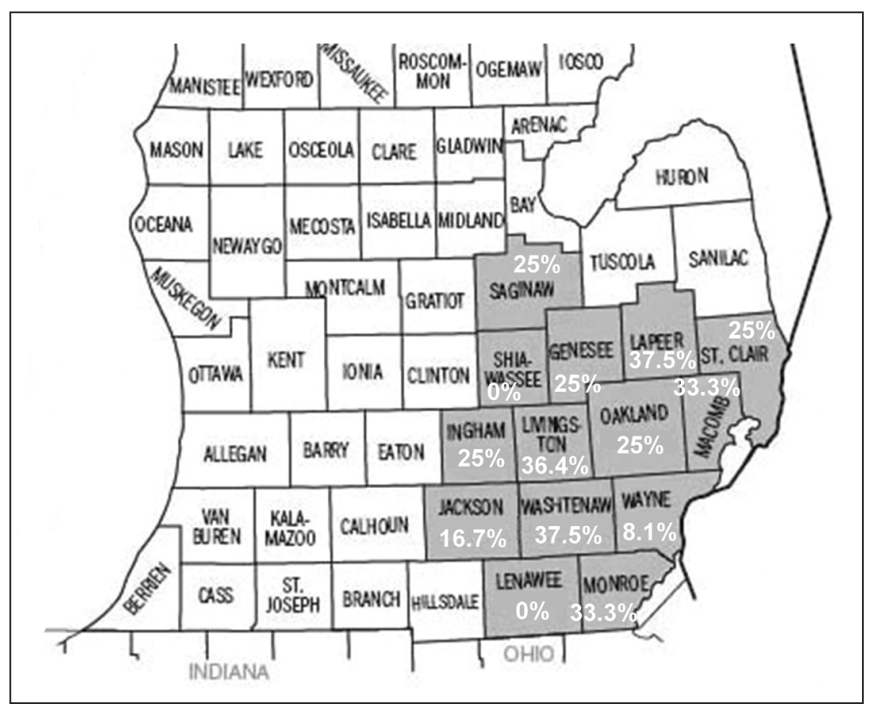

Figure 1. Michigan counties included in the study. Numbers in each county represent the response rate for the county. The average response rate for the region was $23.3 \%$. Adapted from U.S. Census Bureau, Census 2000 Map.
The average response rate for all counties was $23.3 \%$, which is within range of typical response rates for survey studies of this type. A nonrespondent analysis was conducted by evaluating the geographical distribution, sizes, and characteristics of those who did not return the survey. The results indicated no noticeable differences between nonrespondents and respondents of the study.

Companies were classified into types based on their size, equipment, processing capacity, and number of employees. Companies having at least three types of large equipment (including a chipper, stump grinder, chip van, or truck with dump bed) and at least 10 full-time employees were considered large processing facilities. All other respondents were classified as small processing facilities. Based on these criteria, $33 \%$ of the companies were classified as large, and $67 \%$ were small. Data collected from the respondents were extrapolated to determine first, the quantities of wood residue entering yards, and second, the types and volumes of products processed from these yards. This extrapolation was conducted through a method previously used by Alderman et al. (1999) and Alderman et al. (2000).

\section{Field Methods}

Field studies of seven residue yards were conducted to validate mail-survey data, quantify inputs and yields, and identify potential alternatives and bottlenecks. These companies were selected to reflect the diversity of products generated from disposal yards.

A guided discussion was held with each owner or manager during the visits to obtain technical information about the yard size, total number of employees, major equipment, types of wood products/residues accepted, and products produced. No large disparity was observed between data from face-to-face interviews and mail-in surveys. Averages derived from the study were presented to yard owners and observed trends were discussed and validated. Extended discussions were also conducted to assess each owner or manager's strategic vision for the future of wood residue processing in southeastern Michigan.

\section{RESULTS AND DISCUSSION}

\section{Survey Data}

\section{Characterization of wood waste processing facilities}

Respondents provided data that allowed the study authors to estimate 1,082 full-time employees. The average number of employees for a large yard was 7.5, while small yards averaged 4.8 (Table 1). The data also indicated that $78.5 \%$ of the large yards have their own field crews for tree removal and trimming operations, while only $31 \%$ of smaller yards had field crews (Table 1). The finding suggests that larger yards, by operating field crews that produce and collect their own wood residues, have a more reliable incoming base of wood resources, as compared to smaller yards, which had a tendency to depend more on drop-offs from other tree care companies.

All facilities owned a combination of heavy-duty and light equipment, although the most common types of equipment varied between large and small operations (Table 2). The specific types of equipment typically found in the small yards clearly indicated their need to provide specialized, value-added services, such as delivering processed products, producing other products such as firewood, or creating solid wood products. 
Table 1. Employment statistics.

\begin{tabular}{llll}
\hline Characteristics & Large yard & Small yard & Total \\
\hline $\begin{array}{l}\text { Proportion of total } \\
\text { Average number of } \\
\text { employees per yard }\end{array}$ & $33 \%$ & $67 \%$ & - \\
$\begin{array}{l}\text { Estimated total number of } \\
\text { employees all yards }\end{array}$ & 440 & 4.8 & - \\
$\begin{array}{l}\% \text { of businesses with own } \\
\text { field crews }\end{array}$ & $78.5 \%$ & 582 & 1,082 \\
\hline
\end{tabular}

Table 2. Equipment ownership among wood disposal yards (according to yard size).

\begin{tabular}{lcc}
\hline Equipment & Large & Small \\
\hline Aerial lift & $0 \%$ & $3.4 \%$ \\
Backhoe & $14.3 \%$ & $10.3 \%$ \\
Band mill & $7.1 \%$ & $10.3 \%$ \\
Bulldozer & $35.7 \%$ & $6.9 \%$ \\
Chainsaws & $100 \%$ & $48.3 \%$ \\
Chip van & $42.9 \%$ & $6.9 \%$ \\
Chipper with chip box & $42.9 \%$ & $6.9 \%$ \\
Circular mill & $7.1 \%$ & $3.4 \%$ \\
Coloring unit & $0 \%$ & $3.4 \%$ \\
Denailer & $0 \%$ & $3.4 \%$ \\
Edger & $7.1 \%$ & $3.4 \%$ \\
Excavator & $7.1 \%$ & $0 \%$ \\
Fork lift & $50 \%$ & $24.1 \%$ \\
Forwarder processor & $0 \%$ & $3.4 \%$ \\
Hand chipper & $64.3 \%$ & $20.7 \%$ \\
Horizontal grinder & $7.1 \%$ & $3.4 \%$ \\
Kiln/air-dry area & $7.1 \%$ & $3.4 \%$ \\
Loader & $14.3 \%$ & $13.8 \%$ \\
Log splitter & $78.6 \%$ & $31 \%$ \\
Portable mill & $7.1 \%$ & $10.3 \%$ \\
PTO chipper & $14.3 \%$ & $3.4 \%$ \\
Pup-dump & $14.3 \%$ & $0 \%$ \\
Screener & $0 \%$ & $3.4 \%$ \\
Skidder & $11.8 \%$ & $0 \%$ \\
Slabsaw & $7.1 \%$ & $0 \%$ \\
Stump grinder & $57.1 \%$ & $0 \%$ \\
Stump grinder & $7.1 \%$ & $27.6 \%$ \\
Truck scales & $7.1 \%$ & \\
Truck with dump bed & $78.6 \%$ & $0 \%$ \\
Tub grinder & $21.4 \%$ & \\
Whole tree chipper & $64.3 \%$ & $0 \%$ \\
Wood working equipment & $14.3 \%$ & \\
\hline & & $0 \%$ \\
\hline
\end{tabular}

Table 3. Average tipping fee charged by wood residue facilities in $\$ / \mathrm{m}^{3}$. In the study, $12.2 \%$ of businesses were reported charging a tipping fee for any material.

\begin{tabular}{lrrcc}
\hline & Logs & Stumps & Brush and branches & Pallets and scrap wood \\
\hline Mean & $\$ 10.70$ & $\$ 14.27$ & $\$ 8.41$ & $\$ 9.56$ \\
Min & $\$ 7.65$ & $\$ 9.94$ & $\$ 7.65$ & $\$ 7.65$ \\
Max & $\$ 13.76$ & $\$ 19.11$ & $\$ 9.94$ & $\$ 11.47$ \\
\hline
\end{tabular}

Table 4. Average price paid by wood waste yards for wood supply in $\$ / \mathrm{m}^{3}$. In the study, $17.1 \%$ of businesses reported buying these materials.

\begin{tabular}{lccc}
\hline & $\begin{array}{l}\text { Average paid } \\
\text { for logs }\end{array}$ & $\begin{array}{l}\text { Average paid } \\
\text { for sawdust }\end{array}$ & $\begin{array}{l}\text { Average paid } \\
\text { for shredded bark }\end{array}$ \\
\hline Mean & $\$ 117.24$ & $\$ 10.59$ & $\$ 25.43$ \\
Min & $\$ 105.94$ & $\$ 5.30$ & $\$ 19.42$ \\
Max & $\$ 128.55$ & $\$ 31.78$ & $\$ 31.78$ \\
\hline
\end{tabular}

\section{Raw material sourcing and supply}

Tree removal companies were the most common source of wood residues, with approximately two-thirds of the businesses surveyed (65.1\%) handled these types of materials. The second most common wood source was from land clearing operations (used by $44.2 \%$ of respondents), followed by pallets and crates (16.3\%), and lastly mill residues (11.6\%).

A limited number of yards (12.2\%) reported charging a tipping fee to accept wood residues (Table 3). Companies charging tipping fees generally had procedures for screening material arriving at their yards and were generally large, well-established facilities. The tipping fees were typically based on the level of difficulty in processing the material and the potential for converting the residue into useful, salable products. Raw materials that are very difficult to process, with minimal potential for salable products (such as stumps), were generally charged the highest fees $\left(\$ 14.27 / \mathrm{m}^{3}\right.$ on average), and material (such as brush and branches) that are easy to move around and process were charged the lowest fees $\left(\$ 8.41 / \mathrm{m}^{3}\right)$. Logs were charged a medium fee $\left(\$ 10.70 / \mathrm{m}^{3}\right)$ due to the amount of energy needed for their conversion into other materials.

Few residue yards $(17.1 \%)$ reported buying raw material for their processing facilities (Table 4). For instance, the yards willing to pay for raw material (such as logs, sawdust, or shredded bark) generally relied more on tree removals for their supplies and also provided financial incentives to other companies to provide these select materials. Additionally, $17 \%$ of those surveyed reported buying and using sawmill residues as part of their supply.

The total volume of wood material entering processing facilities was 6,659 thousand $\mathrm{m}^{3}$ (Table 5). When viewing wood sources by volume, land clearing was found to be the largest supplier, accounting for $60.8 \%$ (or $4,053.3$ thousand $\mathrm{m}^{3}$ ) of the wood residue entering the yards. Tree removals comprised $33.4 \%\left(2,225.2\right.$ thousand $\left.\mathrm{m}^{3}\right)$ of the total wood residue volume, with sawmill residues and pallet materials representing a very small part of the total resource (5.5\% and $0.2 \%$, respectively). This result is similar to the regional pallet volume, which comprised approximately $1 \%$ of the nation's estimated production of 500 million wooden pallets (Forest Products Laboratory 2007).

From the land clearing supply origin, most residues fell into one of two categories, logs and/or branches/brush/wood chips, with each group contributing 1,911.8 thousand $\mathrm{m}^{3}$ (or $47 \%$ of all land clearing residues). Mulch and stumps represented only a small portion $(6 \%)$ of the land clearing total (Table 5).

Almost half of the materials from tree removals were delivered in the form of wood chips $\left(1,103.1\right.$ thousand $\left.\mathrm{m}^{3}\right)$. Branches and brush made up $10 \%$ of the tree removal residues; and logs represented $8 \%$ of this total. This indicates a clear tendency of tree service companies to convert logs immediately into wood chips, which may be due to a lack of heavy lifting and trucking equipment.

Consideration of all wood sources indicate that most logs arriving at processing facilities are cut into small, easy-to-handle sizes. The study results indicated that only $5 \%$ of the total volume of logs received ( 0.08 million green tons) arrived in "millable" condition (at least ten inches in diameter and eight feet long).

A large number of wood residue processing facilities (85\%) reported a change in the volume of solid wood collected during the past few years, reporting a $75 \%$ to $85 \%$ decrease in their wood supply since 2001 . The bulk of the decrease occurred between 2005 and 2007, when facilities observed a 50\% drop in the wood supply. The downturn was generally attributed to drops 
in land clearing activities due to the decline of new housing construction. Facilities also reported receiving more industrial pallets and crates, and described most of their incoming tree residues as brush. Two other factors were identified as deterrents for the disposal of wood residues: the increase in imports of cheap wood-composite pallets from various overseas sources and the short-term creation of government-subsidized, free, wood disposal yards by EAB eradication programs.

\section{Production}

Wood residue processing facilities produced several products, with roughly half of those surveyed producing wood chips or firewood, and almost a quarter producing mulch or lumber. A lesser number of businesses reported produc-

Table 5. Source of supply of wood waste yards in southeastern Michigan in $1000 \mathrm{~m}^{3}$.

\begin{tabular}{|c|c|c|c|c|c|}
\hline & Types & Small & Large & Total & $\begin{array}{l}\text { Percentage } \\
\text { of total } \\
\text { supply }\end{array}$ \\
\hline \multirow[t]{5}{*}{ Land clearing } & Wood chips & 65.8 & 731.5 & 797.3 & \\
\hline & $\log s$ & 4.5 & $1,907.4$ & $1,911.8$ & \\
\hline & $\begin{array}{l}\text { Branches } \\
\text { and brushes }\end{array}$ & 0.1 & $1,128.9$ & 1,129 & \\
\hline & Mulch & -- & 213.2 & 213.2 & \\
\hline & Stump & -- & 2 & 2 & \\
\hline \multicolumn{2}{|c|}{ Source total } & 70.2 & 3,983 & $4,053.3$ & $60.86 \%$ \\
\hline \multirow[t]{2}{*}{ Pallets } & Scrap pallets & -- & 11.6 & 11.6 & \\
\hline & $\begin{array}{l}\text { Wood chips } \\
\text { from pallets }\end{array}$ & -- & 2.5 & 2.5 & \\
\hline \multicolumn{2}{|c|}{ Source total } & 0 & 14.1 & 14.1 & $0.21 \%$ \\
\hline Sawmill residues & Mixed & -- & 367 & 367 & $5.51 \%$ \\
\hline \multirow[t]{5}{*}{ Tree removals } & Wood chips & 67.3 & $1,035.8$ & $1,103.1$ & \\
\hline & $\log s$ & 7.1 & 107.6 & 114.7 & \\
\hline & $\begin{array}{l}\text { Branches } \\
\text { and brushes }\end{array}$ & 77.2 & 911.9 & 989.1 & \\
\hline & Mulch & -- & 13.6 & 13.6 & \\
\hline & Stump & -- & 4.6 & 4.6 & \\
\hline \multicolumn{2}{|c|}{ Source total } & 151.5 & $2,073.7$ & $2,225.2$ & $33.41 \%$ \\
\hline \multicolumn{2}{|l|}{ Total wood supply } & 221.8 & $6,437.8$ & $6,659.6$ & \\
\hline
\end{tabular}

ing products that included compost, pallets, finished wood products, industrial fuels, topsoil, and playground material. The total production was $2,035.8$ thousand $\mathrm{m}^{3}$ (1.6 million tons), essentially consisting of mulches (representing $42 \%$ of the total production volume) and woodchips (38.6\% of the total). Other common products produced included firewood, industrial fuels, logs, and compost (18.5\% combined of the total production volume) (Table 6).

Approximately $84 \%$ of the total production originated from large yards, while just $16 \%$ was produced by the small yards (Table 6). The greater quantity of production from large yards correlates very well with the relative proportion of the total supply directed to these yards. The bulk of wood chips, mulch, industrial fuels, and logs production were from these larger yards (Table 6). However, the total production of firewood was more evenly distributed between the larger and smaller yards. Among all yards, utilization is predominantly geared toward landscape materials, with mulch and wood chips accounting for $81 \%$ of the total production (Figure 2). Firewood and industrial fuels play a smaller role (collectively representing $13 \%$ of production). Log production (3\% of total) was relatively uncommon.

Reported selling prices varied with the product type and the level of processing (Table 7). As a higher value product, firewood was reported to be sold between $\$ 12.23$ and $\$ 20.71$ per $\mathrm{m}^{3}$. Mulch prices varied between $\$ 8.94$ and $\$ 19.38$ per $\mathrm{m}^{3}$, with hardwood mulch at the lower price point and colored or cedar mulches at the high end price. Compost prices ranged from $\$ 7.82$ to $\$ 11.18$ per $\mathrm{m}^{3}$, and wood chips brought $\$ 1.86$ to $\$ 2.98$ per $\mathrm{m}^{3}$.

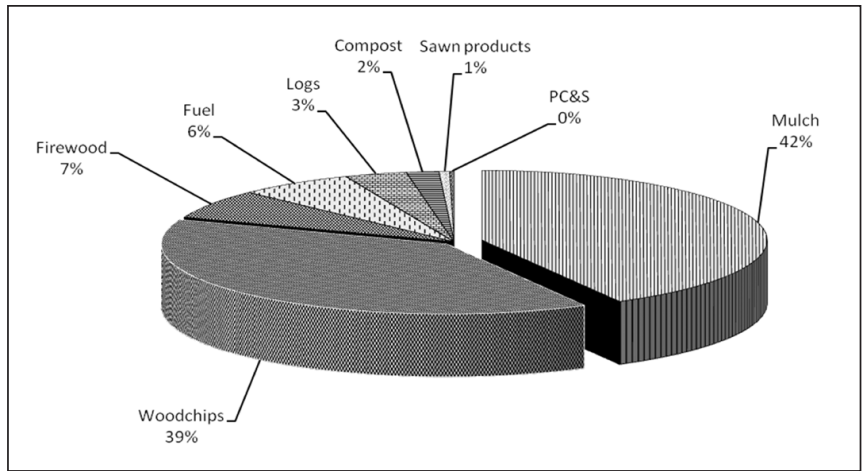

Figure 2. Breakdown of production from wood waste processing facilities in southeastern Michigan.

Table 6. Estimated total production from wood residue yards in $1000 \mathrm{~m}^{3}$.

\begin{tabular}{lcccc}
\hline Type & Large & Small & Total & \% of total production \\
\hline Mulch & 684.8 & 170.3 & 855.1 & $42 \%$ \\
Wood chips & 735.3 & 51.6 & 786.9 & $38.6 \%$ \\
Firewood & 85 & 51.2 & 136.2 & $6.7 \%$ \\
Industrial fuel & 132.7 & -- & 132.7 & $6.5 \%$ \\
Logs & 70.6 & -- & 70.6 & $3.5 \%$ \\
Compost & -- & 37.1 & 37.1 & $1.8 \%$ \\
Sawn products & 9.2 & 2.7 & 11.9 & $0.6 \%$ \\
PC\&S & -- & 5.2 & 5.2 & $0.3 \%$ \\
Total production & $1,717.8$ & 318 & $2,035.8$ & - \\
Percentage & $84.38 \%$ & $15.62 \%$ & - & $100 \%$ \\
\hline
\end{tabular}

Table 7. Price ranges for various products sold from wood residue processing facilities in southeastern Michigan.

\begin{tabular}{lc}
\hline Product & Price range $\left(\$ / \mathrm{m}^{3}\right)$ \\
\hline Hardwood mulch & $8.94-11.92$ \\
Dyed mulch & $14.91-17.89$ \\
Cedar mulch & $14.91-19.38$ \\
Compost & $7.82-11.18$ \\
Wood chips & $1.86-2.98$ \\
Firewood & $12.23-20.71$ \\
\hline
\end{tabular}

\section{Field Data}

Averages obtained from the survey were discussed and validated with owners of the yards visited. They were in general agreement with the survey information presented. Based on observation of their yard operations, the general production and marketing schemes of these yards were mainly oriented toward wood chips and mulch, with only very limited potential for solid wood 
products. During the interviews, yard owners identified two key reasons for the lack of milling activities. First, land clearing operations typically buck logs into short unusable lengths, and second, the costs and challenges of processing and transporting $\log$ are excessive, particularly for owners of the larger yards.

As discerned in the results of the survey questionnaire analysis, yard owners and managers typically criticized the regulation associated with the emerald ash borer eradication program (particularly the free wood disposal yards that were established in southeastern Michigan) as responsible for overall market decline in the region's wood disposal industry. However, many of the companies that were visited are considering new value-added markets, and three major product types were mentioned: production of pellets, exports of mulch and chips to larger metropolitan areas in the U.S. and Canada, and production of fuel for home stoves.

\section{Evaluation of Economic Impact and Potential Alternative Products}

The supply and production data presented here clearly show wood waste processing facilities have a very important economic impact on the region. These processing facilities provide more than 1,000 permanent jobs, while also processing and marketing significant volumes of material necessary for southeastern Michigan landscapes and energy plants. Based on production levels and average selling prices for the various products, the industry contributes $\$ 40$ million to the local economy. However, for a better understanding of the full potential of wood residue processing facilities, a detailed evaluation of the industry is necessary.

The highest-valued utilization of wood residue is typically in the reuse of wood as building materials or interior wood products. However, several barriers currently exist that limit the production of solid wood materials from wood residues. Most wood residues supplied to processing facilities came from land clearing and tree removals. Since land clearing and tree removal activities occur for reasons other than the wood's ultimate use as a product, trees are not evaluated for their grade or product potential before they are harvested and processed. Furthermore, the companies that perform harvesting and processing operations typically have no direct interest, incentive, or equipment to process and handle large $\operatorname{logs}$ in the field. As a result, the logs are usually cut into smaller length for ease of handling, thereby limiting the amount of intact wood available for the higher-valued products.

As it currently stands, the volume of timber-quality logs directed to these yards is too low (less than $5 \%$ of the total wood supply) to justify any serious effort to develop higher-grade solid wood products. It has been demonstrated that wood obtained from land clearing and other tree removals can be milled and used for such items as furniture, trim work, cabinetry, or flooring (Bratkovich 2001; Sherrill 2003). However, access to the appropriate infrastructure, training, equipment, and markets will be necessary to see any significant movement from the wood disposal yard industry in this area. Based on observations made for the present study, it would be possible to increase the relative proportion of $\log$ recovery from $5 \%$ to $30 \%$ of the total wood volume. This could raise the total volume of good quality logs entering disposal yards from 0.08 million tons to 0.48 million tons. Consequently, this also could bring about significant changes in the quality and range of products produced at these yards.
Another critical difficulty in maximizing the value-added potential arises from the uncertainty about the quantities and species a wood residue processing facility can expect to receive in any given period. These factors pose serious supply challenges to any facility owner desiring to specialize in the production of high-end wood products. Despite the current difficult economy, several processing facilities are assessing new market conditions and desire to take advantage of opportunities by developing other types of higher-value end products, such as wood pellets for the domestic, home-use market and for the export market to Canada.

Engineered wood products (e.g., particleboard, oriented strand board, and wood-plastic composites) are another viable product option for this industry (Chow and Zhao 1992). Even when using recovered wood residues, the composite manufacturing process can be achieved if clean and premium materials are used. More research is needed to evaluate the mechanical and physical properties of wood composites manufactured with varying material quality, composition, and species combinations. In addition, a costbenefit analysis should be conducted to fully assess the economic potential of using yard residues for wood composite products.

As both state and federal incentives develop to support a developing bioenergy sector, wood-to-ethanol also emerges as a potential value-added option for wood residues (Petersen et al. 2005). This fermentation process can be done chemically (using acid hydrolysis) or biochemically (using enzymes), resulting in a product that can be purified and distilled to produce liquid fuel. Biomass feedstocks also can be used to produce other biofuels. Thermal processes can be used to convert the biomass directly to a synthesis gas (syngas) composed of carbon monoxide and hydrogen. However, residues from processing yards would have to be combined with wood from other sources to produce the quantities necessary to supply chemical processing facilities. Therefore, clear standards defining the acceptable properties and conditions of the raw materials would need to be developed to maintain efficient biochemical processes.

\section{CONCLUSIONS}

The goal of this study was to assess the collection and processing of wood residue resources in southeastern Michigan and to evaluate potential products for this material. The study found a total 180 facilities and 23 landfills were operating in the study area's 14 counties, employing an estimated 1,082 people. A total volume of $6,659.6$ thousand $\mathrm{m}^{3}$ (5.3 million tons) was supplied to processing facilities leading to a production volume of 2,035.8 thousand $\mathrm{m}^{3}$ (1.6 million tons). This corresponds to a conversion rate of approximately $30 \%$, leaving significant opportunity for additional wood recovery and product development efforts. Merchantable logs represented only $5 \%$ of the total supply volume, too small to economically justify any extensive effort to develop conversion processes into value added solid wood products. Bottlenecks for improved processing included the handling of trees and logs at the harvesting site, accessibility, and the need to invest in expensive equipment with low potential returns. However, the study suggests that with proper equipment and training, the proportion of quality logs directed to wood residue processing facilities could be increased from $5 \%$ to $30 \%$ of the total supply, thus creating a large enough supply, and economically justifiable for a strategic shift towards value-added solid wood products. In addition, if processing facilities create a sorting mechanism to separate wood by quality, this will help maximize the potential value for each load arriving at yards. 


\section{LITERATURE CITED}

Alderman, D.R., R.L. Smith, and V.S. Reddy. 1999. Assessing the availability of wood residues and residue markets in Virginia. Forest Products Journal 49(4):47-55.

Alderman, D.R., and R.L. Smith. 2000. Solid wood received and marketed by Virginia's landfill facilities. Forest Products Journal 50(6):39-44.

Bratkovich, S.M. 2001. Utilizing municipal trees: Ideas from across the country. NA-TP-06-01, St. Paul, MNI: USDA, Forest Service, Northeastern Area, State and Private Forestry. 50 pp.

Chow, P., and L. Zhao. 1992. Medium density fiberboard made from phenolic resin and wood residues of mixed species. Forest Products Journal 42(10):65-67.

De Hoop, C.F., S. Kleit, S.J. Chang, R. Gazo, and M.E. Buchart. 1994. Survey and mapping of wood residues users and producers in Louisiana. Forest Products Journal 47(3):31-37.

Forest Products Laboratory. 2002. Successful approaches to recycling urban wood wastes. Gen. Tech. Rep. FPL-GTR-133, Madison, WI: USDA, Forest Service, Forest Products Laboratory. 20 pp.

Grushecky, S.T., D.W. McGill, and R.B. Anderson. 2006. Inventory of wood residues in southern West Virginia. Northern Journal of Applied Forestry 23(1):47-52.

Haviarova E., C. Eckelman, and Y. Erdil. 2001. Design and testing of wood school desk frames suitable for production by low technology methods from waste wood residues. Forest Products Journal 51(5):79-88.

Hubing, N.R. 1993. Wisconsin wood residue study. Wisconsin Department of Natural Resources. Madison, Wisconsin. 25 pp.

McCullough, D.G., and N.W. Siegert. 2007. Estimating potential emerald ash borer (Coleoptera: Buprestidae) populations using ash inventory data. Forest Entomology 100(5):1577-1586.

McKeever, D.B. 1998. Wood residual quantities in the United States. Biocycle 39(1):65-68

McKeever, D.B. 2003. Quantifying the flow: Taking inventory of woody residuals. Biocycle 44(7):311-35.

Murphy, J.A., P.M. Smith, and J. Wiedenbeck. 2007. Wood residue utilization in Pennsylvania 1988 vs. 2003. Forest Products Journal 57(4):101-106.

Nzokou, P., T. Petrice, R.A. Haack, and D.P. Kamdem 2006. Treatment of Emerald Ash Borer Infested Logs from Southeastern Michigan. Forest Product Journal 56(5):78-81.

Petersen, C.E., E.O. Berg, and L. Ronnegard. 2005. Quality control of waste to incineration - Waste composition analysis in Lidkoping, Sweden. Waste Management \& Research 2005(23):527-533.

Sherrill, S.B. 2003. Harvesting Urban Timber: A guide to making better use of urban trees. Linden Publishing Inc., Fresno, CA. 200 pp.

Sherrill, S.B., and D. MacFarlane. 2007. Measures of Wood Resources in Lower Michigan: Wood Residues and the Saw Timber Content of Urban Forests. Technical Report. Southeast Michigan Resource Conservation and Development Council and the U.S.D.A. Forest Service. 178 pp.

Short, P.H., and T.R. Hooper. 1996. Production and utilization of industrial wood and bark residues in Mississippi. Food \& Fiber Center, Cooperative Extension Service. Mississippi State University. Mississippi State, MS. $45 \mathrm{pp}$.

Pascal Nzokou (corresponding author)

Department of Forestry

Michigan State University

East Lansing, MI 48824, U.S.

Jessica Simons

Southeast Michigan Resource Conservation and Dev. Council 7203 Jackson Road

Ann Arbor MI 48103-9506, U.S.
Anthony Weatherspoon

Department of Natural Resources

P.O. Box 39452

Lansing, MI 48909, U.S

Résumé. Cet article traite d'une analyse des installations de disposition et de transformation des résidus de bois dans le Sud-ouest du Michigan aux États-Unis. L'analyse a été faite dans le but de caractériser les divers types de surplus de bois, d'évaluer le taux de récupération et d'identifier les alternatives potentielles pour les résidus de bois. Les installations de collecte et de transformation ont été identifiées et décrites à l'intérieur d'un territoire composé de 14 comtés. Cette étude a permis de documenter au moins 180 sites de traitement des résidus de bois dans la région qui faisaient appel à une moyenne de six employées par site (pour un total de 1082 employées dans l'industrie). Le volume total de bois entrant au sein de ces sites a été quantifié à 6659,6 milliers de mètres cubes (5,3 millions de tonnes métriques), généralement en provenance de travaux de déboisement et d'abattage d'arbres. Les résidus de bois étaient utilisés pour produire un total 2035,8 milliers de mètres cubes (1,6 million de tonnes) de nouveaux produits (ex.: copeaux de bois, paillis, bois de chauffage) qui étaient vendus localement. Le taux de récupération général était estimé à $30 \%$ pour l'industrie complète, ce qui indiquait clairement qu'il y avait une marge pour l'amélioration. On estime que cette industrie contribue pour approximativement 40 millions de dollars US dans l'économie du Michigan. Une amélioration du taux de récupération et le développement de produits à valeur ajoutée vont nécessiter des changements fondamentaux dans les équipements, la formation et les procédés employés auprès des entreprises de services arboricoles et de déboisement.

Zusammenfassung. Diese Studie ist eine Analyse von den holzverarbeitenden und entsorgenden Einrichtungen in Südwest-Michigan, US. Die Analyse wurde geleitet, um die Wege der Holzlieferung zu charakterisieren, die Rückgewinnung zu evaluieren und mögliche Alternativen für Holzreste zu identifizieren. In einem Areal von 14 Landkreisen wurden die Einrichtungen zum Holzsammeln und -verarbeiten identifiziert und befragt. Diese Studie dokumentierte mindestens 180 aktive Holzsammelstellen in der Region, die durchschnittlich sechs Angestellte pro Hof (von ingesamt $1082 \mathrm{An}$ gestellten in der Branche) beschäftigten. Das Gesamtvolumen von angeliefertem Holz wurde mit 6.659,6 Tausend Kubikmeter (5,3 Millionen Tonnen) angegeben, überwiegend aus Rodungen und Fällungen. Die Lieferungen von Holzabfall wurde verwendet, um insgesamt 2.035,8 Tausend Kubikmeter (1,6 Millionen Tonnen) an neuen Produkten (z. B. Holzschnitzel, Mulch, Bauholz) zu produzieren, die überwiegend lokal verkauft wurden. Die allgemeine Ausnutzungsrate wurde für die gesamte Industrie mit $30 \%$ geschätzt, was Raum für Verbesserung zeigt. Diese Industrie trägt schätzungsweise USD 40 Mill. zur Wirtschaftsleistung von Michigan, US bei. Eine Steigerung der Ausnutzungsrate und die Entwicklung von höherwertigen Produkten würde grundsätzliche Veränderungen in Ausrüstung, Training und Arbeitsprozessen bei den Rodungs- und Baumfällunternehmen erfordern.

Resumen. Este reporte es un análisis de las facilidades de manejo y reciclaje de residuos del sureste de Michigan, U.S. El análisis fue conducido para caracterizar los patrones de oferta de madera, evaluar la eficiencia de reciclaje, e identificar las alternativas potenciales para los residuos maderables. La recolección de madera y las instalaciones fueron identificadas y tasadas a través de un área de 14 condados. Este estudio documentó al menos 180 terrenos de residuos de madera operando en la región, los cuales ocuparon un promedio de seis empleados por predio (para un total de 1,082 empleados en la industria). El volumen total de madera entrando a los predios fue cuantificada en 6,659.6 miles de metros cúbicos (5.3 millones de toneladas métricas), principalmente de la limpieza de terrenos y remoción de árboles. Los residuos de madera fueron usados para producir un total de 2,035.8 miles de metros cúbicos (1.6 millones toneladas) de nuevos productos (astillas de madera, mulches, leña), los cuales principalmente fueron vendidos localmente. La tasa de conversión total fue estimada en $30 \%$ para la industria, indicando claramente espacio para el mejoramiento. Se estima que la industria contribuye aproximadamente con \$40 millones de dólares a la economía de Michigan. El mejoramiento de las tasas de conversión y valor añadido del producto podría requerir cambios fundamentales en equipo, entrenamiento, y procesos usados por las compañías de limpieza de terrenos y servicios de árboles. 